\title{
Vergi Uyuşmazlıklarının Çevrim İçi Çözümü: Türk Vergi Yargı Sistemi Üzerine Değerlendirme
}

\section{Mine Binis $^{\mathrm{a}}$}

Öz: Uyuşmazık, herhangi bir hukuki ilişkinin varlığı, işleyişi ve sonuçları bakımından en az iki taraf arasında ortaya çıkan anlaşmazlıktır. Her alanda yaşanması muhtemel bu anlaşmazlıkların yapısı, internet kullanımının yaygınlaşması ve bilişim teknolojilerindeki gelişmelere bağlı olarak çeşitlilik göstermiştir. Bu değişim uyuşmazlıkların niteliğinde ve çözüm yollarında farklııklar meydana getirmiştir. Uyuşmazlıkların çözümünde teknolojinin "dördüncü bir taraf" olarak çözüm sürecine dahil olmasıla birlikte, bir değişim hareketi ortaya çıkmıştır. Bu dönüşüm uyuşmazlık çözüm sistemleri içerisine çevrim içi çözüm yollarının dahil edilmesi fikrini doğurmuştur. Çevrim içi çözüm yolu internet üzerinden hızlı, basit, daha az maliyetli şekilde uyuşmazlıkların giderilmesini amaçlayan bir yöntemdir. Çalışmanın amacı, çevrim içi yolların Türkiye'de uygulama alanını incelemek ve yargı aşamasında vergi uyuşmazlıklarının çözümlenmesinde uyuşmazlık çözüm sistemleri içerisine dahil edilebilirliğini ele almaktır. Bu doğrultuda teori, ülke uygulamaları, mevcut yasal düzenlemeler ve yargılama ilkeleri üzerinden açıklamalar yapılmıştır. Bu değerlendirmeler neticesinde Türkiye'de çevrim içi çözüm yollarının kısmen uygulandığı ve hukuk yargılamasında uygulama alanı bulan eADR'nin, gerekli yasal düzenlemelerle vergi yargılamasında da uygulanabileceği sonucuna ulaşılmıştır.

\section{Online Resolution of Tax Disputes: An Assessment on The Turkish Tax Judiciary System}

\begin{abstract}
A dispute is a conflict that occurs between at least two parties in terms of existence, functioning and results of any legal relationship. The structure of these disputes, which are likely to be experienced in all areas, has varied depending on the widespread use of the internet and developments in information technologies. This alteration has generated differences in the nature of the disputes and its resolution. Together with the participation of the technology as "the fourth party" in resolution of the disputes a change movement has emerged. This transformation has led to the idea of including online solutions in dispute resolution systems. Online resolution way is a method aiming to resolve the disputes fast, simple and less costly via internet. The study aims to evaluate the application areas of online resolutions and to consider the availability of incorporating online dispute resolution ways into the dispute resolution system for resolving tax disputes in the judicial process in Turkey. From this point, evaluations have been made on the theory, country practices, existing legal regulations, and judgement principles. As a result of these evaluations, it has been concluded that the online resolution of disputes is partially implemented in Turkey and e-ADR, which have application areas in civil law proceedings, can also be applied in tax proceedings with the necessary legal regulations.
\end{abstract}

Anahtar Sözcükler: Çevrim İçi Uyuşmazlık Çözümü (ODR), Elektronik Alternatif Çözüm Yolları (e-ADR), Vergi Uyuşmazlı̆̆ı, Vergi Yargısı

JEL: K30, K34, K41, 033

$\begin{array}{ll}\text { Geliş } & : \text { 20 Mart } 2021 \\ \text { Düzeltme } & : \text { 20 Mayıs } 2021 \\ \text { Kabul } & : \text { 07 Haziran } 2021 \\ \text { Tür } & : \text { Derleme }\end{array}$

Keywords: Online Dispute Resolution (ODR), Electronic Alternative Dispute Resolutions (e-ADR), Tax Dispute, Tax Judgement

JEL: K30, K34, K41, 033
Received : 20 March 2021

Revised : 20 May 2021

Accepted : 07 June 2021

a Assoc. Prof., PhD., Balikesir University, Faculty of Economics and Administrative Sciences, Department of Public Finance, Balikesir, Turkiye, mbinis@balikesir.edu.tr (ORCID ID: 0000-0002-3296-4627) 


\section{Giriş}

Vergi uyuşmazlıkları, vergilendirme sürecinin herhangi bir aşamasında vergi ilişkisinin tarafları arasında ortaya çıkan ihtilaflardır. Vergi uyuşmazlıkları geleneksel çözüm yolları olarak ifade edilen idari ve yargısal yollar ile çözümlenmektedir. Bununla beraber 1990'lı yıllardan itibaren dijitalleşme sürecinin etkisiyle, uyuşmazlık çözüm sistemlerinde geleneksel yollarla birlikte çevrim içi yolların uygulanabilirliğine yönelik bir yönelim oluşmuştur. İlk olarak uyuşmazlıkların çözümünde alternatif çözüm yöntemlerinin (Alternative Dispute Resolution-ADR) sürece dahil edilmesi ile değişim başlamıştır. Akabinde ise alternatif çözüm yöntemlerinden elektronik ortamda yararlanılmasını sağlayan e-ADR yöntemi ve yargılama sürecinin çevrim içi ortamda gerçekleştirilmesine yönelik uygulamalar ortaya çıkmıştır. Özellikle e-ticaret kaynaklı uyuşmazlıklarda çevrim içi çözümlerin başarısı, bu yolların uyuşmazlık çözüm sistemlerinin geneline yaygınlaştırılması eğilimini kuvvetlendirmiştir.

Çevrim içi çözüm yolları bilişim teknolojilerinden yararlanılarak, internet üzerinden uyuşmazlığın giderilmesini amaçlayan bir anlaşmazlık çözüm tekniğidir. Bu yenilikçi çözüm yolları günümüzde sadece alternatif çözüm yollarına internet üzerinden erişim sağlama sürecini değil; yargı organlarına çevrim içi ortamda başvurulması, davanın görülmesi ve hüküm verilmesi aşamalarının sanal mahkemeler vasıtasıyla çevrim içi ortamda gerçekleşmesi süreçlerini de kapsamaktadır. Bu çalışmanın amacı vergi uyuşmazııklarının yargı organlarınca çözümünde çevrim içi çözüm yollarının uygulama alanını ve imkânını incelemektir. Bu kapsamda öncelikle çevrim içi çözüm yollarının kavramsal çerçevesi ele alınacak olup, bu yolların halihazırda hangi uyuşmazlıklar için kullanıldığı üzerinde durulacaktır. Çalışmanın sonunda diğer ülke örneklerinden de hareketle, Türk vergi yargı sisteminde yenilikçi bu yolların hukuksal ve teknik açıdan değerlendirilmesine yer verilecektir.

\section{Uyuşmazlık Çözüm Sistemi Tasarımı: Çevrim İçi Çözüm Yolu}

Her ülkenin hukuk sistemi içerisinde ortaya çıkan uyuşmazlıkların çözümüne yönelik uyuşmazlık sistem tasarımı yapılmaktadır. Sistem tasarımı sadece münferit uyuşmazlıkların çözümünü değil, uyuşmazlıkların bir bütün halinde ele alınmasını içeren bir dizi prosedürün oluşturulmasını içermektedir (Jone, 2015). Uyuşmazlık çözüm sisteminin düzenlenmesini ve uygulanmasını kapsayan sistem tasarımı çeşitli hedefleri barındırmaktadır. Öncelikli hedef, uyuşmazlığın çözümüne ilişkin maliyetlerin azaltılmasıdır. Maliyetleri teşkil eden kalemler ise işlem maliyetleri, prosedür ve sonuçlardan memnuniyet, prosedürlerin taraflara uzun vadede etkisi ve anlaşmazlıkların tekrarlanmasından oluşmaktadır. Diğer önemli bir konu da uyuşmazlık sistemlerinin, anlaşmazlıkların uyuşmazlığa dönüşmeden ve anlaşmazlık aşamasında yapılan müzakereler ile çözülmesini sağlayacak yapıda düzenlenmesidir (Mookhey, 2013). Burada asıl üzerinde durulması gereken mevzu, uyuşmazlığın hukuk kurallarına uygun şekilde giderilmesini sağlayacak bir sistemin oluşturulması ve uygulanabilirliğinin yasal zemine oturtulmasıdır.

Uyuşmazlıkların çözüm süreci, müzakerede olduğu gibi tarafların tam kontrole sahip olduğu yöntemler, sürecin tarafsız üçüncü şahıs tarafından yönetildiği yollar ve/veya yargı organlarınca yürütülmesi şeklinde farklı süreçlere dayalı olarak gerçekleştirilebilir (Cortés, 2014: 172). Bilişim teknolojilerinin gelişimi ile tüm bu süreçlerin çevrim içi ortamda yazııımlar vasıtasıyla gerçekleştirilebilmesi üzerinde durulmaktadır.

1990 'lı yıllardan itibaren uyuşmazlıkların çevrim içi yollarla sonuca bağlanmasına yönelik modeller geliştirilmeye başlanılmıştır. Çevrim içi uyuşmazlık yollarının gelişiminde pragmatik ve ideolojik olmak üzere iki motive kaynağı etkili olmuştur. Bir fikir olarak ortaya çıkması ve uygulamaya geçmesinde etkili olan birincil faktör; çevrim içi faaliyetlerdeki ve internet kullanıc sayısındaki artış ve elektronik ticarettir. İkinci faktör ise "adalete etkili erişim" hareketi, uyuşmazlıkların çözümünde "verimlilik paradigması" ve bunlarla ilgili alternatif çözüm yollarına başvuru sürecidir (Sela, 2017: 636). Bu çözüm yollarının kavramsal çerçevesi üzerinde durulması önem arz etmektedir.

Çevrim içi çözüm yolları "başvuru, değerlendirme, kanıt ve delil sunma, çevrim içi müzakereler ve karar verme sürecini" de içeren süreçlerin çevrim içi gerçekleştirilmesidir (Cortés, 2014: 172). "ODR" (Online Dispute Resolution) kısaltmasıyla 1990'lı yılların ortalarından itibaren literatürde kullanılmaya başlanılmıştır. ODR kavramına ilişkin genel kabul gören bir tanımlama bulunmamakla birlikte çeşitli çalışmaları esas alarak 
izah getirilebilir. Xu, Zhang ve Gao (2008) çalışmalarında ODR'yi internet gibi elektronik ağlar vasıtasıyla yürütülen bir süreç olarak; Latifah, Bajrektarevic ve Imanullah (2019) ise küresel uyuşmazlık çözüm sürecinin sembolü olan bir bilgi teknolojisi ürünü şeklinde tanımlamışlardır. Salter (2017:113) daha geniş bir ifadeyle ODR'yi, "müzakere, arabuluculuk, uzlaştırma, tahkim ve diğer yargılamalar dahil olmak üzere herhangi bir uyuşmazlığın çevrim içi olarak ve geleneksel bir fiziksel ortam dışında çözümlendiği bir süreç" olarak ifade etmiştir. Clark, Cho ve Hoyle (2003: 8) çalışmalarında ODR'yi; internet veya türevleri (kurum içi ağlar-intranet, mobil telefon, video konferans ve uydu gibi çeşitli teknolojiler) üzerinden erişim ve elektronik ortamda belge alma ve gönderme olanakları sunan vasıtalar şeklinde açıklamışlardır. ODR esasen uyuşmazlıkların kanuni düzenlemelere uygun bir şekilde çevrim içi yollar ile giderilmesi sürecidir.

Çevrim içi çözüm yollarının gelişimi irdelendiğinde alternatif çözüm yolları ile bilişim teknolojileri arasındaki sinerjiden ortaya çıktığı gözlemlenmektedir. Çevrim içi çözüm yolları çevrim içi veya çevrim dışı ortamdan kaynaklanan uyuşmazlıkların çözümlenmesine yönelik hizmetleri kapsayabilir (Ramasastry, 2004). Birçok ODR sisteminde insan faktörüne ihtiyaç duymaksızın otomatik olarak; bazı ODR sistemlerinde ise üçüncü bir tarafın sürece dahil olmasıyla uyuşmazlıklar çözümlenmektedir (Ziemblicki, 2018: 46). ODR'nin kavramsal çerçevesine ve işleyişine ilişkin açıklamaların yanı sıra olumlu ve olumsuz yanlarına ve uyuşmazlık çözümündeki rolüne de değinilmesi icap etmektedir.

\section{3. Çevrim İçi Çözüm Yollarının Potansiyeli ve Uyuşmazlıklardaki Rolü}

Çevrim içi çözüm yollarının kullanım alanının genişlemesiyle birlikte birçok soru da sorulmaya başlanmıştır. Temel soru ODR'yi geleneksel çözüm yollarından ayıran özellik nedir? Bir ikinci soru da geleneksel çözüm yolları üzerindeki etkisi ne olacaktır? Bu sorulara yanıt, ODR'nin potansiyel avantaj ve dezavantajları perspektifinden verilebilir.

ODR uygulamaları birçok avantajı içermektedir. Söz konusu avantajlar genellikle hız, elverişlilik, adalete erişim kolaylığı, verimlilik, maliyet tasarrufu, dijital verilerin kolay depolanması ve erişimi gibi nitelikler üzerinde yoğunlaşmaktadır (Clark vd., 2003; Austin, 2018). Bu avantajların yanında tarafların uyuşmazlığın çözümü için fiziksel olarak bir araya gelme zorunlulukları olmaması da birçok maliyetin azalmasına (ulaşım, konaklama gibi) katkı sağlayacaktır. Hâkim veya arabulucunun iş akışından bağımsız olarak ODR ile herhangi bir zaman diliminde uyuşmazlığın çözümüne, anlaşmaların e-posta, tartışma grupları veya web siteleri üzerinden oluşturulmasına ve değişikliklerin de aynı yolla yapılmasına ortam hazırlanmaktadır. Ayrıca ODR, tarafların niteliğine uygun kişiselleştirilebilir teknikler uygulanmasına da fırsat sunmaktadır (Pappas, 2008).

ODR bu avantajlarının yanı sıra çeşitli sakıncalar da doğurabilir. Öncelikle müzakere ve arabuluculuk gibi çözüm yolları temelde insan odaklı süreçlerdir. Üçüncü taraf olan müzakereci, uzlaştırıcı veya arabulucu ODR'nin uygulandığı durumlarda sözlü olmayan ama yargıya varmasında emare olabilecek vücut dili ve tutumları değerlendirme fırsatından yoksun kalmaktadır. Bu yoksunluk geleneksel yoldan ayrıştıran olumsuzluklara neden olabilir. Uzlaştırıcının ses tonu, beden dili ve mimikleri ile taraflar arasında oluşturduğu güven ortamı çevrim içi yollarda aynı oranda kurulmayabilir (Clark vd., 2003: 9). Ayrıca ODR'nin zaman ve maliyet tasarrufu sağlama özelliği tüm uyuşmazlıklarda geçerli olmayabilir. Uyuşmazlığın niteliğine bağlı olarak çevrim içi yollar da aynı nispette zamana yayılabilir ve maliyete yol açabilir. Rabinovich Einy ve Katsh (2014) çalışmalarında ODR'nin "her derde deva bir çözüm yolu olmadı̆̆ı", ancak özellikle adalet ve erişilebilirlik bakımından birçok potansiyeli barındırdığı sonucuna ulaşmışlardır. ODR bahsedilen zayıf yanlarıyla birlikte, özellikle uyuşmazlıkları kısa bir süre içinde çözüme kavuşturma ve sisteme kolaylıkla erişme imkânı sağlama yönleri ile uyuşmazlıkların çözümünde güçlü potansiyele sahip bir yöntemdir.

Çevrim içi çözüm yollarının uyuşmazlıklardaki rolüne ilişkin yaygın görüş bu yolların geleneksel yollar ile yarışacak bir etki doğurabileceğidir. Uyuşmazlıklar geleneksel yollar olarak ifade edilen idari ve yargısal çözüm yollarında giderilebileceği gibi, tarafsız üçüncü kişilerin yer aldığı alternatif yollar ve teknolojinin bir taraf olarak yer aldığı çevrim içi ortamlarda da çözümlenebilir. 1990'lı yıllarda ODR sadece e-ticaret kaynaklı anlaşmazlıkların internet üzerinden çözümlenmesi şeklinde kısıtlı bir alanda uygulanmıştır. 2000'li yılların 
başından itibaren ise ODR diğer uyuşmazlıkları da içine alacak şekilde uyuşmazlıkların çözümündeki rolü artmıştır (Austin, 2018). Bu gelişmede teknoloji önemli bir görev üstlenmiştir.

Teknoloji uyuşmazlık çözüm sürecinde, tarafların bağımsız ve üçüncü tarafla iş birliği içinde anlaşmaya varılmasında yardımcı bir vasıta "dördüncü taraf" olarak rol oynamaktadır. Teknolojik araçlar ile çevrim içi kimlik doğrulaması, sürecin idamesi, kanıtların işlenmesi, çevrim içi mahkemelerin doğasından kaynaklanan sorunların giderilmesine olanak sunulabilir. Pappas (2008)'e göre teknoloji “güven mimarisi” oluşturulmasına, kapsamlı bir çevrim içi yargılama ve ODR kapasitelerinin geliştirilmesine katkıda bulunabilir. Teknolojinin sağladığı imkânlar dahilinde ODR kullanım alanları her geçen gün genişlemektedir.

\section{4. Çevrim İçi Çözüm Yollarının Kullanım Alanları ve Usulleri}

Çevrim içi çözüm yollarının kullanım alanları bilişim teknolojilerine duyarlı olarak gelişme göstermeye açıktır. ODR kullanım alanları dar ve geniş anlamda ele alınacaktır.

\subsection{Elektronik ADR Uygulamaları}

Çevrim içi çözüm yolları öncelikle alternatif çözüm yolları ile uygulamaya geçirilmiştir. Alternatif çözüm yollarına internet üzerinden erişimi ifade eden elektronik alternatif çözüm yolları (e-ADR), ODR'nin dar anlamını teşkil etmektedir. e-ADR; müzakere, arabuluculuk, tahkim gibi yüz yüze gerçekleşen çözüm süreçlerinin ağ tabanlı bir eşdeğeri olması görüşü ile ortaya çıkmıştır (Rabinovich Einy ve Katsh, 2014). Bu yolların uyuşmazlıklarda uygulanabilirliği tartışımaktadır. Cortés (2014) çalışmasında vaka olayları (CyberSettle, ePay ve PayPal, Modria, mahkeme temelli arabuluculuk) üzerinden e-ADR'lerin uygulanabilirliğini değerlendirmiş ve uyuşmazlıkların hızlı, basit ve ucuz şekilde çözümünde kayda değer sonuçlar doğurduğunu ve ilerleyen yıllarda öncelikli bir çözüm yolu olabileceğini ifade etmiştir.

Çevrim içi uyuşmazlık sistemi kapsamında, alternatif çözüm yolları farklı yöntemler ile uygulanabilir. Bu yöntemler başlıca aşağıdaki şekilde açıklanabilir:

- Arabuluculuk: Anlaşmazlık yaşayan taraflar arasındaki bir istişare sürecidir. Arabuluculukta tarafların tarafsız üçüncü bir kişi olan arabulucunun önderliğinde bir araya gelerek sorunlarını açıklığa kavuşturmaları ve anlaşmazlığa düşülen konuya ilişkin çözüm seçenekleri sunulması amaçlanır (Carabetta, 2017). Böylece taraflar anlaşmazlık konusuna ilişkin görüşlerini ifade etme, kanıt sunma ve çözüm için fikirlerini ifade etme fırsatına sahip olmaktadırlar. Arabulucu karar verme yetkisine sahip olmayıp, sadece taraflar arasında yaşanan uyuşmazlığın çözümünde yardımcı bir rol üstlenmektedir (Stilwell, 2014: 28).

- Tahkim: Üçüncü bir kişi tarafından kanıtlar, deliller incelendikten sonra anlaşmazlık konusu hakkında karar verilmesi sürecidir (Cortés, 2010: 68). Arabuluculuktan farklı olarak tahkimde, uyuşmazlık konusu olayın çözümüne ilişkin tarafsız bir hakem tarafından yön verilmektedir. Tahkim kararları bağlayıcı olabileceği gibi, bağlayıcı olmayabilir de. Bağlayıcı olmayan tahkimde hakemin kararı tavsiye niteliğindedir (Verma, Banwari ve Pande, 2018: 141).

- Müzakere: İki veya daha fazla taraf arasında bir anlaşmaya varılabilmesi adına teklifler, karşı teklifler ve karşııklı ödün verme sürecini içerir (Dimov, 2017: 33). Müzakere, arabuluculuk ve tahkimden farklı olarak üçüncü bir tarafın müdahalesini içermez. Burada çözüm tamamen uyuşmazlık yaşayan tarafların karşılıklı anlaşmaya varmalarına dayanır. Süreç gizli yürütülmekte ve gönüllülük esasına bağlı gerçekleşmektedir. Taraflar istedikleri zaman uzlaşmaktan vazgeçebilirler (Benyekhlef ve Gélinas, 2005: 44).

E-ADR ile tüm bu çözüm yollarının internet ağı üzerinden çevrim içi şekilde gerçekleştirme olanağı sunulmaktadır. Bu alternatif yollardan müzakerenin çevrim içi gerçekleşmesinin iki yöntemi mevcuttur. İlki otomatik müzakere (kör teklif) olup, taraflar uyuşmazlığın çözümüne yönelik diğer tarafın haberi olmaksızın teklifte bulunmakta, bu teklif ve talepler bilgisayar programı aracılığıyla karşılaştırılmakta ve iki rakamın aritmetik ortalaması tutarında miktarda uzlaşmaya varılmış sayılmaktadır. íkinci şekli ise destekli müzakeredir. Bu yöntemde taraflar internet üzerinden çevrim içi imkânlar (web tabanlı iletişim araçları, video 
konferanslar gibi) dahilinde üçüncü bir kişinin katılımı olmaksızın bir araya gelerek birbiriyle iletişime geçerler. Otomatik müzakere sadece parasal uyuşmazıık konuları ile sınırıdır (Schultz, 2002). Alternatif çözüm yolları içinden daha çok arabuluculuk ve tahkim çevrim içi gerçekleştirilmektedir.

E-ADR'ler yargı aşaması öncesi veya yargılama sırasında uyuşmazlıkların çözümünde bir yöntem olarak uygulanabilir. Dava açmadan önce bu yollara başvurulması, yargılama giderlerine katlanmaksızın uyuşmazlığın sona ermesini sağlayabilir. Mahkeme temelli olarak da e-ADR uygulanabilir. Açıklamalardan anlaşıldığı üzere e-ADR hem yargı öncesi hem de mahkemelerde uygulama alanı olan bir çözüm seçeneğidir.

\subsection{Mahkemelerde Uygulama Alanları}

Günümüzde geleneksel yargılama usullerinde yaşanan sorunlar, yargılama sürecinde değişim ihtiyacını ortaya çıkarmıştır. Bu ihtiyaç kapsamında, standart bir uygulaması olmamakla birlikte, ODR'ler yargı organlarında uygulama alanı bulmuştur. ODR'nin geniş anlamda uygulaması kapsamında; sadece alternatif uyuşmazlık yollarının teknoloji ile birleştirilerek uygulanmasının ötesinde, mahkemeler tarafından uyuşmazlığın optimal bir şekilde çözümüne katkı sağlayacak gerçek bir dizi değişimi içermektedir. ODR ile amaçlanan uyuşmazlıkların yargısal çözümünde başvuru aşamasından hüküm verilmesine kadar tüm aşamalarda teknolojik imkânların kullanımının sağlanmasıdır. Bu uygulamalar doğrudan ODR veya farklı ifadelerle (e-duruşma, sanal mahkemeler, dava yönetimi) adlandırılmaktadır (Ebner ve Greenberg, 2020: 70).

Yargı usullerinin ve esaslarının çevrim içi gerçekleştirilmesi, mahkemelerin iç işleyişine fonksiyonel anlamda katkıda bulunabilir. ODR'ler belgelerin elektronik ortamda dosyalanması ve paylaşılması, duruşma günlerinin planlanıp, duyurulması sürecini de içermektedir. Bu sürecin çevrim içi ortam üzerinden yapılması ile zaman ve emek tasarrufu sağlanarak mahkemelerin iç işleyişinde verimlilik sağlanabilir. Bilişim teknolojileri yardımıyla mahkeme prosedürleri ve duruşmalardaki gecikmeler azaltılabilir (Schiavetta, 2005). Mahkemelerde ODR uygulaması sadece idari işlemlerin çevrim içi gerçekleştirilmesini değil, duruşmaların çevrim içi ortamda yapılmasını da içerebilir. Sanal mahkemeler (e-duruşma) olarak ifade edilen bu fikir ilk olarak 1990'lı yıllarda ortaya atılmıştır. Bu şekilde duruşmaların gerekli teknolojik altyapının tesisi ile dava taraflarının mahkemeye gelmesine gerek kalmaksızın, çevrim içi ortamda yapılması ve karara bağlanması amaçlanmıştır (Pappas, 2008). Ayrıca e-duruşma yolu ile dava işlem maliyetlerinin azaltılmasına ve yargılamanın temel ilkelerinden biri olan usul ekonomisine hizmet etme anlamında fayda sağlanabilecektir.

Birçok ülkede mahkemelerde uygulama alanı bulan ODR'ler, başlıca iki temel amaca yönelik hayata geçirilmiştir. Bu amaçlar; mahkemelerin verimliliğini artırmak ve adalete erişimi kolaylaştırmaktır. Ülke bazında ilk kez Avustralya'da 1999 yılında hazırlanan Teknoloji ve Hukuk adlı raporda mahkemelerin geleceğine ilişkin çeşitli tavsiyelere yer verilmiştir. Raporda herkesin adalete kolay bir şekilde erişimini sağlamak amacıyla, mahkemelerde ve yargılama sürecinde teknolojinin avantajlarından yararlanma imkânı sunulması tavsiye edilmiştir (Clark vd., 2003: 14). Uluslararası alanda yapılan çalışmalara 2013 tarihinde gerçekleştirilen "Adalete Erişimi Yaygınlaştırmada Teknolojinin Kullanımı Zirvesi" kapsamında hazırlanan rapor örnek oluşturmaktadır. Rapor doğrultusunda bütünleşmiş bir hizmet sunumuna yönelik beş temel bileşene dikkat çekilmiştir. Bunlar (Sharmila, 2020: 38):

- Yasal bir portalın oluşturulması.

- Belge yönetim sürecinin düzenlenmesi.

- Mobil teknolojilerden yararlanarak daha fazla kişiye etkin hizmet sunulması.

- Adalete erişim imkânlarını artırmak amacıyla iş analiz süreci uygulanması.

- Avukatlara ve diğer hizmet sağlayıcılarına yönelik uzman sistemler geliştirilmesi.

Yukarıda bahsedilen bileşenlerin yanı sıra mahkemelerde ODR uygulamasına ilişkin standartlar geliştirilmesi de önem arz etmektedir. Avrupa Komisyonu bu doğrultuda yedi ana ilke benimsemiştir. Bunlar; tarafsızlık, şeffaflık, çelişmeli yargılama usulü, temsil, tüketici bilinci ve özgürlüğü, verimlilik ve erişilebilirlik ve yasallık ilkelerinden oluşmaktadır (Clark vd., 2003: 18). Bu ilkeler yargı organlarında ODR uygulamasına 
yön verecek ilkeler olmakla birlikte, asıl konu bu ilkelerin çevrim içi çözüm yollarında uygulamasına ilişkin yasal mevzuatın oluşturulması ve hangi uyuşmazlıklar için uygulanabileceğini saptamaktır.

Pappas (2008)'a göre mahkemelerde e-ADR kullanımı küçük miktarlı parasal uyuşmazlıklar ve daha az karmaşık konular için ideal bir uyuşmazlık çözüm yoludur. Ayrıca adli yargının doğası gereği idari yargı koluna göre, çevrim içi yolların daha başarılı sonuçlar vereceği belirtilmiştir. Bununla birlikte Rabinovich Einy ve Katsh (2017) çalışmalarında ODR'nin kamusal alanlara da uyarlanabileceğini, e-ADR'nin küçük miktarlı uyuşmazlıkların çözümünde uygulanabileceği, ancak karmaşık uyuşmazlıklar için uygun olmayacağı sonucuna ulaşmışlardır. Cortés (2010)'a göre ODR kullanım alanının sınırlı olduğuna ilişkin bazı yanılgılar mevcuttur. Bu yanılgılar e-ADR'nin küçük miktarlı uyuşmazlıklarda, internet kaynaklı uyuşmazlıklarda ve yalnızca çevrim içi ortamdan kaynaklı uyuşmazıklarda kullanım alanının olacağına dayanmaktadır. Ülke uygulamalarından da görüleceği üzere günümüzde bu yolların kullanım alanı genişlemiş ve sadece internet kaynaklı (e-ticaret) uyuşmazlıkların çözümünde değil, diğer uyuşmazlıkların çözümünde de yararlanılan bir yöntem haline gelmiştir.

\section{Yargı Organlarında Çevrim İçi Çözüm Yolları Ülke Uygulamaları}

Yargı organlarında çevrim içi yolların uygulama şekli her ülkede ayrı bir seyir izlemektedir. Yargılama sürecinde $O D R^{\prime} l e r i n$ sadece idari işlemlerin yürütülmesi aşamasında mı? Uyuşmazlık çözüm sistemi kapsamında e- ADR şeklinde mi? Yoksa davanın görülmesi ve karara bağlanma aşamasını da kapsayacak biçimde mi uygulanacağı? her ülkenin teknolojik altyapısına ve hukuki mevzuatına dayalı olarak şekillenmektedir. Bu bağlamda ilk örnek olarak aşağıda Amerika Birleşik Devletleri'ne yer verilmiştir.

ABD'de ODR uygulamaları 1996 yılında başlatılan Sanal Yargıç Projesi ve Online Ombudsman adıı iki proje kapsamında yürütülmüştür. Sanal Yargıç Projesi; fikri mülkiyet ihlalleri, hakaret, dolandırıcılık ve yanıltıcı ticaret uygulamaları alanlarında yaşanan anlaşmazlıkların çevrim içi ortamda çözümlenmesine yönelik geliştirilmiş bir arabuluculuk hizmetidir. Sanal yargıç, anlaşmazlığın çözümünde daha resmi bir "amaç" sunar ve mahkeme kararına geçici bir çözüm olarak görülür. Diğer bir proje olan Online Ombudsman uyuşmazlıkların çözümüne yönelik tesis edilmiş olmakla birlikte daha gayri resmidir ve esnek bir temele dayanmaktadır. Burada arabuluculuk için belirlenmiş prosedürler yer almamakta ve kararlar bağlayıcılık arz etmemektedir. Taraflar arabuluculuk hizmetinden hiçbir ücret ödemeden çevrim içi yararlanabilmektedir. Hizmet alanları genellikle haber ajansları, siber rakipleri, internet servis sağlayıcıları, alan adı anlaşmazlıkları, spam iddiaları ve telif hakkı anlaşmazlıklarından oluşmaktadır. 2001 yılında ABD'de ilk olarak Michigan eyaletinde ticari uyuşmazlıkların çözümünde mahkemelerde ODR uygulamaya geçmiştir. Tarafların tamamının rıza göstermesi halinde sanal mahkeme üzerinden yargılama faaliyeti yapılmaktadır. Bu şekilde görülecek davalarda parasal sınır 25.000 ABD Doları'nın altında olmalıdır (Clark vd., 2003).

ODR uygulamasına ilişkin ikinci bir ülke örneği olarak Kanada gösterilebilir. Kanada'da ODR'ler ilk kez E-çözüm uygulaması altında, alan adına ilişkin uyuşmazlıklarda tatbik edilmiştir. E- çözüm uygulamasından yeni bir proje olan sanal yargıç projesi doğmuştur. 1997 yılında yürürlüğe giren sanal yargıç projesi ile eticareti teşvik etmek amacıyla ekonomik ve gizli bir arabuluculuk ve tahkim hizmetleri sunulması amaçlanmıştır. Bu proje bir yazılım programı vasıtasıyla tüketicilerin ve satıcıların müzakere etmesi ile anlaşmazlıkların çözümüne dayanmaktadır. Diğer bir proje ise Siber Adalet Laboratuvarıdır. Bu kapsamda basit ve erişilebilir telekonferans sistemleri, engelli kişiler için erişimi iyileştirecek teknolojiler, mahkeme belgeleri hazırlama araçları gibi çeşitli modüller oluşturulmuştur (Gregory, 2011). Kanada'da ODR'lerin kamu hukukundan kaynaklı uyuşmazlıklarda bir çözüm yolu olarak uygulanması düşüncesi ilk kez 2011 yılında gündeme gelmiştir. British Columbia eyaletinde kâr amacı gütmeyen bir kuruluş olan Consumer Protection BC tarafından, tüketicilerin korunmasına yönelik düzenlenmiştir. Uyuşmazlıkların çözümünde çevrim içi yollar bir ODR sağlayıcısı olan Modria tabanlı sistem üzerinden kullanılmaya başlanmıştır. Yine aynı yılda, ODR'ler bir idari mahkeme olan BC Mülkiyet Değerlendirme Temyiz Kurulu tarafından uygulamaya geçirilmiştir. Bu mahkemede ODR'den, meskûn emlak vergisi tahakkuklarına ilişkin yaşanan uyuşmazlıklarının çözümünde yararlanılmıştır (Salter, 2017: 117). Tüm bu açıklamaların yanı sıra Kanada dünyadaki yargı sistemleri içinde ODR sisteminin tamamen entegre olduğu ilk ülke olması bakımından önem arz etmektedir. Kanada'nın çevrim içi mahkemesi Medeni Hukuk Mahkemesidir. Bu mahkeme kapsamında interaktif bilgi kaynaklarına ve 
müzakere, arabuluculuk gibi çeşitli uyuşmazlık çözüm yollarına erişim sağlanmaktadır. Taraflar, tüm ODR hizmetlerine istedikleri zamanda bilgisayar veya mobil cihazlarından ulaşabilmektedirler. Teknolojiyi kullanamayan veya kullanmak istemeyenler için fiziksel olarak veya telefon tabanlı hizmetler de vermektedir (Salter, 2017: 114). Uyuşmazlık miktarı 25.000 Kanada dolarını aşmayan çeşitli alacak davalarına ilişkin uyuşmazlıkların çözümünde bu mahkemeye başvurulabilir. Ayrıca mahkemenin yetki alanında; trafik kazalarına ilişkin anlaşmazlıklar, parasal bir sınır olmaksızın kat mülkiyetine ilişkin anlaşmazlıklar, kooperatifler ve birliklerde yer almaktadır (Ebner ve Greenberg, 2020: 76). Uyuşmazlıkların çözümü iki aşamada gerçekleştirilmektedir. ilk aşamada "Çözüm Gezgini" şeklinde tabir edilen sistem kapsamında kullanıcılara detaylı sorular sorularak uyuşmazlıkların niteliğinin ortaya konulması amaçlanır. Uyuşmazlık niteliği tespit edildikten sonra, çözüme yönelik seçenekler sunulur. Ağustos 2018 itibariyle bu sisteme yapılan 7.142 başvurudan, 4.574 tanesi çevrim içi çözüm yolu ile giderilmiştir (Larson, 2019).

Diğer bir ülke uygulaması kapsamında Avustralya üzerinden izah getirilebilir. Avustralya'da diğer ülke uygulamalarına benzer bir gelişim süreci yaşanmış, öncelikle mahkeme temelli e-ADR'ler ile ODR süreci başlatılmıştır. Sidney'de bir ilk olarak elektronik tahkim odası oluşturulmuştur. Ağ bağlantılı oda ile; elektronik kanıt, belge görüntüleme, video konferans, web yayını ve harici hizmetlere erişim fırsatı sunulmaktadır. Bu şekilde tahkikat öncesi sürecin kısaltılması ve uyuşmazlıkların daha hızlı çözümlenmesi amaçlanmıştır (Schiavetta, 2005).

ODR ülke uygulamalarına son olarak ise İngiltere ve Çin üzerinden açıklama yapılacaktır. İngiltere'de Galler Hukuk Mahkemeleri Yapı Raporu çevrim içi mahkeme uygulamasının başlatılmasına öncülük etmiştir. Bu mahkemede başlangıç aşamasında 25.000 sterline kadar hukuk yargılamasına ilişkin uyuşmazlıklara yargılama yetkisi verilmiştir. Çevrim içi Çözümler Mahkemesi olarak da adlandırılan bu mahkemede süreç dilekçeler, tahkikat ve hüküm olmak üzere üç aşamadan oluşmaktadır (Ebner ve Greenberg, 2020: 76). Çin'de ilk defa 2017 yılında Hangzhou şehrinde çevrim içi mahkemeler uygulamaya geçirilmiştir. Mahkemede eticaretten kaynaklanan tüketici anlaşmazlıkları, ürün sorumluluğu davaları ve internet sağlayıcılarına ilişkin uyuşmazlıklar görülmektedir (Ebner ve Greenberg, 2020: 78). Bu ülke örneklerinin ötesinde çevrim içi yargılamada robotların yargıç gibi kullanılması görüşü de ortaya atılmıştır. Estonya, küçük uyuşmazlık miktarlarına ilişkin uyuşmazlıkların çözümüne ilişkin 2019 yılında "Robot yargıç" projesini yargılama fonksiyonunu üstlenmesi için hayata geçirmiştir (Li, Bao, Hu, Hu ve Zerbino, 2020). Tüm bu ülkelerde öne çıkan durum, çevrim içi yolların daha ziyade e-ticaret kaynaklı uyuşmazlıklar ve parasal bir sınırı olan hukuk yargılamasına ilişkin uyuşmazlıklarda kullanıldığıdır. Aşağıda ise vergi uyuşmazlıklarında çevrim içi çözüm yolları uygulamasına ilişkin değerlendirmeler yapılacaktır.

\section{Vergi Yargı Sisteminde Çevrim İçi Çözüm Yolları}

Vergi yargı sistemleri ülkelerin benimsedikleri hukuk sistemine bağlı olarak değişiklik göstermektedir. Tüm hukuk sistemlerinde ortak amaç, ortaya çıkan vergi uyuşmazlıklarının kanuni düzenlemelere uygun şekilde yargısal denetimini gerçekleştirmek ve uyuşmazlığı çözümlemektir. Farklı paydaşlar arasında yaşanması muhtemel anlaşmazlıklardan vergi uyuşmazlıkları ve vergi yargısında çözümünün ayrı bir değerlendirmeye tabi tutulması gereklidir.

Vergi hukuku, kamu gücü yetkileri ile donatılmış ve idari yargılama usulü ilkelerinin uygulandığı bir hukuk dalıdır. Bu bağlamda eşitlik ilkesinin ve medeni yargılama usulü ilkelerinin uygulandığı özel hukuktan hem maddi hukuk bakımından hem de usulen farklılık göstermektedir. Özel hukukta yer alan "bireysel yarar, şekil serbestisi, kanuna aykırı olmadan serbestçe hukuki ilişkiye girme ve bu ilişkiye son vermenin iradi olması" ilkelerine kıyasla; kamu hukukunda "kamu yararı, şekle bağlılık, kanuna bağlı kalarak hukuksal ilişkiye girme zorunluluğu, kanuni sebebe dayanarak hukuksal ilişkiye son verme zorunluluğu" gibi amaç ve yöntem açısından ayrım bulunmaktadır (Arat, 2011: 894).

Konuya vergi uyuşmazlıklarının yapısal farklıığı açısından bakıldığında ilk göze çarpan durumlardan biri vergi uyuşmazlıklarına ilişkin davaların makro etkilere neden olabildiğidir. Vergi davaları sonucu verilen kararlar sadece vergi idaresi ile vergi mükellefi arasında bir etki doğurmayabilir (Hidayah, 2018: 1). Söz konusu kararlar toplumun tümüne etki doğurabilecek yerleşik bir içtihat haline gelebilir. Dolayısıyla vergi 
uyuşmazlıkları özel hukukta olduğu gibi sadece taraflar arası değil, topluma da sonuçları yansıyabilecek bir etki alanına sahip olabilir.

Vergi yargı sisteminde uyuşmazlıkların çözümünde dikkate alınması gereken bir husus da yargılamaya egemen olan ilkelerdir. Uyuşmazlıkların çözümünde vergilerin kanuniliği ilkesi ve eşit muamele ilkesine uygun hareket edilmelidir. Kanunilik ilkesi gereğince, vergi idaresi ile vergi mükellefleri arasındaki tüm ilişkilerin yasal bir boyut içinde yürütülmesi zorunludur. Bu ilke vergi idaresi ile vergi mükellefleri arasında yaşanan vergi uyuşmazlıklarının çözümünde genel hukuk kuralından farklılık göstermesi nedeniyle bir sınır teşkil edebilir. Özel hukukta taraflar serbestçe tasarruf edebilmekle birlikte, vergi uyuşmazlıklarında taraflardan biri olan vergi idaresinin serbestçe tasarruf etme hakkı yoktur. Bazı alanlarda takdir yetkisi tanınmakla birlikte bu yetki ancak kanunda belirtilen sınırlar dahilinde kullanılabilir. İdari yargı içinde yer alan vergi yargısında tarafların eşitliği ilkesi geçerli değildir. Kamu yararını temsil eden vergi idaresi daha üstün olsa da bu durum idare ile vergi mükellefleri arasında yaşanan bir anlaşmazlık halinde güç dengesizliği olduğu anlamına gelmemektedir. Aslında teknik olarak eşit güçte olmama diğer uyuşmazlıklarda da muhtemeldir (Hout, 2018).

Diğer hukuk dallarından ayrıştıran ve vergi uyuşmazlıklarının doğasından kaynaklanan farklııklarla birlikte, vergi yargısının dahil olduğu idari yargılamada yeni çözüm yollarının uygulanabilirliğinin çalışmalara konu edinildiği görülmektedir. Arat (2011) çalışmasında özel hukuk ile kamu hukuku arasındaki usul farklılıklarının, kamu hukukunda alternatif çözüm yollarının uygulamasına etkisini incelemiştir. Çalışmasında adli yargılamada benimsenen menfaat odaklı yaklaşım ile idari yargılamada benimsenen kamu yararı yaklaşımlarının yargılama usullerinde farklılığa neden olduğunu tespit etmiş ve bu durumun alternatif çözüm yollarının uygulamasına da yansıyacağını belirtmiştir. Çalışma sonucunda bu farklılıkların alternatif çözüm yolları bakımından, özellikle tahkimin, idare hukukunun içtihat yoluyla gelişimini engelleyebileceğine, alternatif çözüm yollarında geçerli olan gizlilik ilkesinin idari yargılamadaki alenilik ilkesini zedeleyebileceğine, idari yargılamanın bir işlevi olan idarenin hukuka uygun davranma işlevini tam olarak yerine getirmesini engelleyebileceğine ulaşmıştır. Bununla birlikte çalışmasında yargılama öncesi aşamada, idareye takdir yetkisi tanınan alanlarda yürürlüğe konulacak genel bir idari usul yasası ile alternatif çözüm yollarının uygulama imkânının olabileceği ifade edilmiştir.

Vergi yargılamasında yenilikçi çözüm yollarının dahil edilmesi görüşü yabancı literatürde yer alan birçok çalışmaya da konu olmuştur. Örneğin Xu vd. (2008) çevrim içi çözüm yollarını tarafsızlık ve adalet açısından ele aldıkları çalışmada bu çözüm yollarının kamuda uygulanabilirliğine vurgu yapmışlardır. Schiavetta (2005) uyuşmazlıkların çözümünde vergi idaresi veya çeşitli kamu kurumları aracılığıyla da e-ADR sürecinin yönetilebileceğini özellikle idari anlaşmazlıklar ve idari işlemlere ilişkin itirazların bu yolla çözümlenebileceğini savunmuştur. Kovač (2018) vergi uyuşmazlıklarında alternatif çözüm yollarını Slovenya Cumhuriyeti özelinde değerlendirdiği çalışmasında vergi ilişkisinin tarafları açısından daha fazla adalete erişim imkânı sunma ve prosedürlerin daha hızlı sonuçlanması gibi yararlar sağladığını ortaya koymuştur. Buna karşın çalışmada ADR'lerin uluslararası hukuk ve anayasal idari ilkeler bağlamında kamu yararına ve eşitlik ilkesinin uygulamasına bir tehdit oluşturabileceği, bu nedenle vergi uyuşmazlıklarında sınırlı bir şekilde uygulanmasının gerekli olduğu sonucuna ulaşıımıştır. Sharmila (2020) mahkemelerde ODR kullanımına ilişkin çalışmasında, düzenlenecek standartlar ve yasal düzenlemeler kapsamında çevrim içi yolların adalete erişim imkânında ve adalete olan güven duygusunda artış sağlayabileceği bulgusuna varmıştır. Sourdin (2015) Avustralya'da alternatif çözüm yollarının vergi uyuşmazlıklarında uygulamasını incelediği çalışmasında etkili ADR süreçlerinin zamandan ve maliyetten tasarruf sağlayabileceği, hükümetin karar alma sürecine güven ve kabulünü destekleyebileceği ve vergi mükellefleri ile daha iyi ilişkiler geliştirilebileceği sonucuna ulaşmıştır.

Jone (2019) çalışmasında vergi uyuşmazlıklarında teknolojik gelişmelerin çözüm yollarına dahil edilmesi ile vergi idaresi ile mükellefler arasında kamu güveninin temin edilmesi ve mükelleflerin vergiye gönüllü uyumunda olumlu yönde etkide bulunacağını belirtmiştir. Bununla birlikte tüm uyuşmazlıkların çevrim içi çözüm yolları ile giderilmeye uygun olmadığı ifade edilmiştir. Bunun nedeni tüm mükelleflerin dijital hizmetleri kullanma yeteneğine sahip olmaması, belirli işlemleri telefonla veya yüz yüze gerçekleştirmeyi tercihte ısrar etmeleri veya anlaşmazlığın çevrim içi yollarla çözüme elverişli olmaması şeklinde açıklanabilir.

Her ülkenin yapısal farklılı̆ıına bağı olarak vergi uyuşmazlıklarında ODR uygulama sonuçlarının değişiklik gösterdiği anlaşılmaktadır. Örneğin ABD'de vergi uyuşmazlıklarının çözümünde arabuluculuk yolu ile başarılı sonuçlar elde edilmişken; tam tersine Kanada'da beklenildiği gibi bir çıktı meydana gelmemiş ve 
vergi uyuşmazlıklarının çözümünde arabuluculuk uygulaması sona erdirilmiştir (Hout, 2018). Önemli olan husus her ülkenin yapısal ve teknolojik farklılığına uygun yolları tespit edip, bunları vergi yargı sistemine uyarlayabilmesidir. Ayrıca mükelleflerin bu yollara ilişkin yargısı da başarısı üzerinde etkili olacaktır. Nam ve Walpole (2016) çalışmalarında ifade ettikleri üzere, vergi mükelleflerinin vergi uyuşmazlıklarının çözüm sürecinin adil olduğuna ilişkin algısı, mükelleflerin vergiye gönüllü uyum eğilimini olumlu yönde etkilemektedir. Çalışmalarında vergi uyuşmazlıklarının çözümünün bir sosyal maliyet doğurduğu ve bu maliyetin vergi mükellefleri açısından çözüm yollarına başvuru hakkını engelleyebileceğini ifade etmişlerdir. ODR'lerin uygun tedbirlerin geliştirilmesi ile adalete erişim imkânı kolaylaştırıcı etki doğuracağı, temel hukuk ilkelerine uygun yasal düzenlemelerin bu çözüm yoluna uyumlaştırılmasıyla birlikte uygulanabilirliği üzerinde durulmuştur. Ayrıca vergi uyuşmazlıklarının çözümünde ODR ile dostane ilişkiler kurma, uyuşmazlığın hızlı ve az maliyetli kazan kazan ilişkisi içinde çözümlenme imkânı sunulabilmektedir. Bu doğrultuda vergi uyuşmazlık çözüm maliyetinin azaltılmasında, hızlı ve kolay ve erişebilir bir yol olma nitelikleri taşıyan çevrim içi yollar uygulamaya dahil edilebilir. Bu yenilikçi çözüm yollarının vergi yargı sistemine dahil edilmesi ile yargı fonksiyonuna işlerlik kazandırılabilir.

\section{Türk Yargı Sisteminde Çevrim İçi Çözüm Yolları ve Değerlendirmesi}

Çalışmanın bu kısmında çevrim içi çözüm yollarının Türkiye'de yargı organlarında, özelde ise vergi yargı organlarında, yargı reformları, yargı işlevleri ve hukuk ilkeleri bakımından değerlendirilmesine yer verilecektir.

\subsection{Yargı Reformları ve Yargı İşlevinin Yerine Getirilmesi Bakımından}

Türkiye'de yargı fonksiyonunu yürüten bağımsız mahkemeler, yürürlükteki kanunları uygulayarak uyuşmazlıkları sona erdirmektedir. Davanın açılması ile başlayan yargılama süreci, tarafların karşııklı iddia, savunmada bulunmaları, davanın görüşülmesi ve karara bağlanması aşamalarından oluşmaktadır. Bu sürecin makul olan en kısa sürede tamamlanması, ekonomik ve kolay olması yargılamaya egemen olan ilkeler kapsamında arzu edilen bir durumdur.

Türk hukuk sisteminde geleneksel bir yargılama süreci geçerlidir. Bununla birlikte 1999 yılında yargı teşkilatında e- dönüşüm süreci başlatılmıştır. Bir e-devlet projesi olarak yürürlüğe alınan Ulusal Yargı Ağı Bilişim Sistemi (UYAP) ile yargılamaya işlerlik kazandırıması amaçlanmıştır. Günümüzde UYAP ile Anayasa Mahkemesi, Yargıtay, Danıştay, bölge adliye mahkemeleri, bölge idare mahkemeleri, Türkiye Adalet Akademisi, Hakimler ve Savcılar Kurulu ve Adalet Bakanlığı'nın bağlı ve ilgili kurumları arasında bir bilgi otomasyon sistemi kurulmuştur. UYAP Avukat Bilgi Sistemi ve UYAP Vatandaş Bilgi Sistemi üzerinden çevrim içi olarak dava açma, ödeme, dosya ve duruşma sorgulama, evrak gönderme olanakları mevcuttur (Adalet Bakanlığı, 2021a: 25). Bu portallar yargılama sürecinin çevrim içi ortamda sürdürülmesine yönelik teknolojik altyapıya zemin hazırlamıştır.

Türk yargı sisteminde yargılama sürecinde yenilikçi çözüm yollarının uygulanabilirliği reform çalışmalarına konu edinilmiştir. Yargı reformu stratejileri; ilki 2009 yılında, güncellenmiş hali ile ikincisi 2015 yılında ve son olarak 2019 yılında hazırlanan belgelerden oluşmaktadır. 30.05.2019 tarihinde açıklanan "2023 Yargı Vizyonu- Güven Veren ve Erişilebilir Bir Yargı Sistemi" adlı strateji belgesinde yargıda reforma yönelik amaç ve hedefler belirlenmiş, faaliyetler düzenlenmiştir. Bu amaçlardan "adalette erişimin kolaylaştırılması ve hizmetlerden memnuniyetin artırılması; hukuk yargılaması ile idari yargılamanın sadeleştirilmesi ve etkinliğin artırılması ve alternatif çözüm yollarının yaygınlaştırılması" amacı çalışmanın konusu açısından ayrı bir önem göstermektedir (Adalet Bakanlığı, 2015; Adalet Bakanlığı, 2019). Bu hedefler doğrultusunda yargılamada bilişim sistemlerinin yaygınlaştırılacağı ve buna yönelik teknolojik altyapının tamamlanacağı anlaşılmaktadır. Strateji belgelerinde dikkat çeken bir diğer husus da hedeflerin ve faaliyetlerin daha çok hukuk yargılamasına ilişkin olmasıdır. Buna karşın idari yargılamada dosyanın tekemmül sürecine ilişkin usul işlemlerinin sadeleştirilmesi gibi daha kısıtlı düzenlemelere gidildiği görülmektedir.

Yargı reformu strateji belgelerinde üzerinde önemle durulan bir konu, yargıda bilişim teknolojilerinin ve alternatif çözüm yollarının kullanımının yaygınlaştırılmasıdır. Türk yargı sistemi açısından bu hedefler doğrultusunda çevrim içi çözüm yollarının iki bakış açısıyla incelenmesi gereklidir. Bir tanesi alternatif çözüm 
yollarının elektronik ortamda uygulanması, bir diğeri de yargılama sürecinin çevrim içi ortam üzerinden gerçekleştirilmesidir. Değerlendirmeye ilk olarak alternatif çözüm yolları açısından bakıldığında; Türkiye'de alternatif uyuşmazlık çözüm yöntemlerinin adli yargı kolunda uygulandığı görülmektedir. Tahkim, arabuluculuk ve uzlaşma usulleri bu alternatif yollar kapsamında uygulama alanı bulmaktadır. Çoğunlukla uyuşmazlık yaşayan tarafların iradesine bağlı olarak başvurulan yollar olmakla birlikte, başvurunun zorunlu olduğ $u^{1}$ uyuşmazlık konuları da söz konusudur. Adli Sicil ve İstatistik Genel Müdürlüğü’nden elde edilen verilere göre hukuk uyuşmazlıklarında arabuluculuk sonuçları incelendiğinde dosyalarda önemli oranda anlaşma sağlandığı görülmektedir. İhtiyari arabuluculukta anlaşma sağlama oranı daha yüksek oranda gerçekleşmiştir. 2018- 2019 yıllarına ilişkin ihtiyari arabuluculukta 2018 yılında dosyaların \%94,6'sında; 2019 yılında ise \%98,7'sinde anlaşma sağlanmıştır. Dava şartı arabuluculukta ise 2018 yılında \%69,4; 2019 yılında ise \%58 oranında dosyada anlaşma ile sonuçlanmıştır (Adli Sicil, 2020: 211). Anlaşıldığı üzere arabuluculuğun uyuşmazlıkları sona erdirme konusundaki başarısı kayda değerdir. Bununla birlikte ihtiyari arabuluculukta sürecin, tarafların uyuşmazlığı sona erdirmeye ilişkin olumlu bir tutum içinde olmaları nedeniyle daha hızı gerçekleştiği söylenebilir. Bu alternatif çözüm yollarına halihazırda adli yargıda çevrim içi erişme imkânı bulunmaktadır.

Türkiye açısından e-ADR uygulamalarına UYAP sistemi üzerinden işlerlik kazandırılmıştır. UYAP Arabulucu Portalı ile özel hukuk uyuşmazlıklarında arabulucular portal üzerinden uyuşmazlığa ilişkin gelen işleri ve dosyaları görüntüleyebilmekte, tevdi edilen arabuluculuk görevini kabul/ret işlemini yapabilmekte, sürecin takibini ve sonlandırma işlemlerini gerçekleştirebilmektedirler. Aynı işlemler UYAP Uzlaştırmacı Portalı üzerinden de uzlaştırmacılar tarafından yapılabilmektedir (Adalet Bakanlığı, 2021a: 114, 117). Anlaşıldığı üzere, e- ADR sürecinin tamamı değil, başvuru ve belge görüntüleme gibi süreçler çevrim içi yolla gerçekleştirilmektedir. Bu sürecin tamamının çevrim içi yolla gerçekleştirilebilmesi mümkün müdür? Bu konuda Kadıŏ̆lu (2019) tarafından yapılan çalışma üzerinden açıklama getirilebilir. Çalışmasında Türkiye'de e-ADR'nin uygulanabilirliğini değerlendirmiş ve özellikle B2C e-ticaretten kaynaklanan uyuşmazlıkların çevrim içi yollarla çözümlenebileceği, çevrim içi tahkim yönteminin hem yasal altyapı hem de yapısal olarak uygun olduğu, yargının da bu sürece uyarlanması ile başarılı bir şekilde uygulama imkânı olduğu sonucuna ulaşmıştır.

Türk hukuk sistemine göre alternatif çözüm yolları sadece özel hukuk kaynaklı, kişilerin üzerinde tasarruf edebilecekleri uyuşmazlık konuları için uygulanmaktadır. Bu durum ise vergi uyuşmazlıklarında alternatif yolların uygulanabilirliğinin değerlendirilmesi ve vergi uyuşmazlıklarının çözümünde idari yollar ile alternatif yollar arasında bir karşılaştırma yapılması ihtiyacını doğurmaktadır. Vergi uyuşmazlıklarında ADR uygulama imkânının öncelikle yasal mevzuat açısından incelendiğinde mümkün olmadığı anlaşılmaktadır. Vergi uyuşmazlıklarının çözümünde idari yollar ile ADR karşılaştırması yapıldığında ise her iki yolun da uyuşmazlığın kısa sürede çözümünü temin etme amacını barındırdığı görülmektedir. Bununla birlikte ADR'nin taraflar açısından bir maliyete neden olacağı bir gerçektir. Türk Vergi Hukukunda idari çözüm yolları içinde yer alan uzlaşma kurumuna başvuru mükellefler açısından bir maliyete yol açmamaktadır. Fakat her durumda uzlaşmaya gidilemez. Uzlaşmanın şartlarını karşılayan konularda uzlaşılmaktadır. Mükelleflere uyuşmazıık konusuna ilişkin alternatif yolların sunulması uyuşmazlığın kısa sürede çözümlenmesi açısından önemlidir. Ülke örneklerinden görüldüğü üzere, ADR ve özellikle arabuluculuk vergi uyuşmazlıklarının çözümünde kayda değer bir performans sergilemektedir. Türkiye açısından değerlendirildiğinde bu yolların UYAP Portalı üzerinden vergi uyuşmazlıklarında da teknik olarak kullanılması mümkün hale getirilebilir. Önemli olan eADR'lerin hukuki altyapısının temin edilmesidir. Vergi uyuşmazlıklarında alternatif yolların uygulanmasına yönelik yapılacak mevzuat değişikliği ile UYAP Portalı üzerinden uyuşmazlıkların çözümünde uygulamaya geçirilebilir.

Alternatif çözüm yollarının yaygınlaştırıması amacı kapsamında önemli bir hedef "kamunun taraf olduğu uyuşmazlıklarda sulh yolunun etkili uygulanmasının sağlanmasıdır" (Adalet Bakanlığı, 2019). 02.11.2011 tarihinde 659 sayılı KHK 12. madde ile idari ve adli davalara ilişkin sulh yoluna ilişkin düzenlemeler getirilmiştir. Teknik olarak vergi uyuşmazlıklarında sulh yolu bir alternatif çözüm yolu olarak düşünülebilir mi? Bu soruya vergi uyuşmazlıklarının hangi vergilendirme süreci ile ilgili olduğu üzerinden açıklama getirilebilir. Sulh yoluna başvuruda "somut bir zararın varlığı" aranmaktadır. Somut zararın varlığı şartı vergi uyuşmazlıklarında sulh yolunun uygulama alanını kısıtlamaktadır. Bu nedenle sadece tahsil aşamasına ilişkin 
ortaya çıkan uyuşmazlıkların sulh yolu ile çözümlenebilmesi mümkündür. Yapılacak bir mevzuat değişikliği ile bu şartın aranmaması halinde vergi uyuşmazlıklarında sulh yolu ile uyuşmazlıkların giderilmesi sağlanabilir. Ayrıca bu şekilde uyuşmazlıkların çözümünde yargı öncesi yolların getirilmesi ve yargının iş yükünün azaltılması amacı doğrultusunda bir sonuca ulaşılabilir.

Çevrim içi yolları, yargılama sürecinde teknolojiden mümkün olduğunca çok faydalanılması anlamından yola çıkarak ele alındığında, aslında Türkiye'de e-devlet uygulamaları kapsamında yargı organlarında dijitalleşme adımlarının atıldığı görülmektedir. Daha önce de ifade edildiği üzere tüm yargı kollarında UYAP Portalları üzerinden dava açma, belge görüntüleme imkânı bulunmaktadır. Ayrıca E- Adalet Projesi kapsamında mahkemelerde "Sesli Görüntülü Kayıt ve Video Konferans Sistemi (SEGBiS)" uygulamaya geçirilmiştir. Adalete Daha İi Erişim Projesi kapsamında; 134 Ağır Ceza Merkezinde "duruşmaların sesli ve görüntülü olarak kayıt altına alınması ve mahkemeler arasında eş zamanlı iletişim ile canlı görüşme imkânı" sağlanmıştır (Adalet Bakanlığı, 2021a: 73- 74). ilerleyen yıllarda SEGBiS’nin teknik altyapısının güçlendirilmesi ile yargı sisteminde bu uygulama yaygınlaştırılacaktır. Konuya idari yargı kolu ve özelde vergi yargılaması açısından bakıldığında yazılılık ilkesinin geçerli olmasından dolayı kullanım alanı bulunmamaktadır. Ancak IYUK 17.maddesinde ifade edilen durumların varlı̆ı halinde idari yargıda duruşma yapılabilir. Sistem sadece bu madde kapsamında yapılan duruşmalarda sınırlı bir uygulama alanı olabilir.

Davanın görülme ve hükme bağlanmasının çevrim içi gerçekleştirilmesini ifade eden e- Duruşma uygulaması açısından da konu irdelenmelidir. Hukuk mahkemelerinde uygulama bulan bu yargılama sistemi kapsamında avukatların hukuk mahkemelerinde elektronik olarak Avukat Portal/CELSE üzerinden duruşmalara video konferans ile katılım olanağı sunulmaktadır (Adalet Bakanlığı, 2020b). İlk olarak Ankara Batı 1. Tüketici Mahkemesinde gerçekleşen e-Duruşma uygulaması şu anda Ankara Batı Tüketici, İcra Hukuk ve Kadastro Mahkemeleri ve Ankara, Istanbul, istanbul Anadolu ve Bakırköy Adliyeleri Tüketici Mahkemelerince yürürlüktedir. E-duruşma bilgilendirme platformundan yayınlanan en son rakamlara göre 18 Ocak 2021 itibariyle e-duruşmanın uygulandığı mahkeme sayısı 505'tir (Adalet Bakanlığı, 2021b). EDuruşmanın ülke geneline yayılması amaçlanmaktadır. İdari yargıda SEGBiS uygulaması yapılan açıklamalara uygun olarak e-Duruşmada sadece IYUK 17.madde kapsamında uygulanabilir.

Vergi mahkemelerine taşınan vergi uyuşmazlıkları her geçen yıl artış göstermektedir. 2012-2019 tarihleri arası vergi mahkemelerine gelen dosya sayılarında \%3'lük bir artış olurken, bununla birlikte karara bağlanan dosyalarda değişim ortaya çıkmamıştır. Vergi mahkemelerine 2019 yılında gelen dosyaların \%71,9'u çözümlenmiş, geri kalanı ise bir sonraki yıla devretmiştir. 2019 yılı verilerine göre vergi mahkemelerinde davaların ortalama görülme süresi 121 gündür (Adli Sicil, 2020: 269- 270). Türk vergi yargı sisteminde UYAP Portalı ile yargıda dava açma, dilekçe ve savunma gibi işlemler çevrim içi gerçekleştirilmektedir. Bununla birlikte e-ADR çözüm yollarının uygulanır duruma getirilmesi ile uyuşmazlıkların daha hızlı, etkin ve verimli bir şekilde çözümlenmesi sağlanabilir.

\subsection{Yargılama illkeleri Bakımından}

Vergi yargısının işlevlerinden biri uyuşmazlıkları çözmedir. Bu işlev idari ve vergi yargılamasına ilişkin ana ilkelere uygun yerine getirmelidir. Özellikle yargılamanın basit, hızlı ve ucuz olmasını düzenleyen usul ekonomisi ilkesi göz ardı edilmemelidir. 1982 Anayasasının 141. maddesinde "Davaların en az giderle ve mümkün olan süratle sonuçlandırılması, yargının görevidir" ve Hukuk Muhakemeleri Kanunu 30. maddesinde "Hâkim, yargılamanın makul süre içinde ve düzenli bir biçimde yürütülmesini ve gereksiz gider yapılmamasını sağlamakla yükümlüdür" hükümleri ile usul ekonomisi ilkesi düzenlenmiştir.

Usul ekonomisinin unsurlarından biri uyuşmazlığın hızlı bir şekilde sonuçlandırılmasıdır. Ancak Türk yargı sisteminde yargılama süresinin uzunluğu önemli bir sorunu teşkil etmektedir. Tekbaş ve Hayrullahoğlu (2018) vergi uyuşmazlıklarını makul sürede yargılama hakkı bakımından ele aldıkları çalışmalarında Türkiye'de yargılama süresinin uzunluğunun yapısal bir sorun oluşturduğunu ve bu sorunun giderilebilmesi adına mekanizmaların geliştirilmesi ve düzenlemelerin yapılması gerekliliğini ifade etmişlerdir. Çevrim içi çözüm yollarının yargılama süresini kısaltma hedefi bu anlamda önemli bir çıktı elde edilmesine fırsat sağlayacaktır.

Yargı Reformu Stratejisi'nde açıklanan "hak ve özgürlüklerin daha etkin korunup geliştirilmesi, sistemin şeffaflığının artırılması, yargısal süreçlerin basitleştirilmesi, adalete erişım kolaylaştırılması, savunma 
hakkının güçlendirilmesi ve makul sürede yargılanma hakkının daha etkin korunması" hedeflerinin gerçekleştirilmesinde çevrim içi çözüm yolları yardımcı olabilir. Her türlü bilgi ve belgeye UYAP entegrasyonları üzerinden ulaşılması yargılamanın işlerliğine fayda sağlayabilir. UYAP Bilişim Sistemi Entegrasyonları ile 2020 tarihinden itibaren duruşma bilgileri sorgulama entegrasyonu aracılığıyla Afyonkarahisar, Ankara, Antalya barolarına anlık duruşma bilgileri ve haftalık duruşma listeleri çevrim içi yolla verilmeye başlanmıştır (Adalet Bakanlığı, 2021a: 49).

Çevrim içi çözüm yolları adalete erişim hakkı kapsamında da değerlendirmeye alınmalıdır. Adalete erişim hakkı, "yargı organlarına başvuru imkânına sahip olmanın yanı sıra, yargıya başvurmaya yönelik engellerin ve sınırlandırmaların tespit edilerek kaldırılmasını ve yargıya başvuranın yargılama usul ve esaslarına göre en kısa sürede, en az giderle hakkına ulaşma güvencesinin verilmiş olmasını" ifade eder (Özkan, 2015: 399). Toplumdaki herkesin kolay bir şekilde adalete erişimini sağlama konusunda çevrim içi çözüm yolları beklenen çıktıları temin edebilir.

Yargılamaya ilişkin ana ilkelere uygun "güven veren ve erişilebilir bir adalet sistemi" oluşturma gayesi kapsamında çevrim içi çözüm yolları ile Anayasa 36. maddesinde düzenlenen hak arama hakkını kullanmak isteyenlere 7 gün 24 saat yargı organlarının ulaşılabilir olması olanağı sağlamaktadır. Herkesin kolay bir şekilde adalete erişimi ve adalet hizmetlerinden memnuniyetin artırılmasında çevrim içi çözüm yolları önemli bir araçtır. Ayrıca adil yargılanma hakkı adalete erişim hakkı, makul sürede yargılanma hakkı gibi temel diğer ilkeleri de içinde barındırmaktadır.

COVID-19 ile mücadele kapsamında hazırlanan "Adalet Hizmetlerinde Koronavirüs Tedbirleri Kapsamında Yeni Çalışma Esasları Kılavuzu" (2020a) ile yargılama masraflarının mobil ödeme araçları ile ödenmesine yönelik tedbirler alınmış, mahkemelerde fiziksel temasın azaltılması kapsamında SEGBiS sisteminin kullanımının artırılmasına yönelik faaliyetler belirlenmiştir. Aynı zamanda hukuk yargılamasında UYAP portalları üzerinden tarafların iddia ve savunmada bulunabilmeleri, dava dosyasına ulaşabilmeleri adil yargılamada olmazsa olmaz silahların eşitliği ilkesi ve çelişmeli yargı ilkelerine de işlerlik kazandırmaktadır. COVID-19 sürecinde daha önce fiziki ortam üzerinden yapılan başvuruların ve değerlendirmelerin çevrim içi yollar ile uygulanıyor olması yargıya işlerlik kazandırıması açııından önem arz etmektedir. Vergi uyuşmazlıklarının Türk yargı sisteminde çözümünde dava açma, belge görüntüleme gibi işlemlerin bir kısmı çevrim içi yapılabilmektedir. Çevrim içi yolların uygulanmasında, e-ADR'ler haricinde herhangi bir yasal engel yoktur. Teknolojik altyapının oluşturulması, gerekli ikincil mevzuat değişikleri ve idari faaliyetler ile çevrim içi alternatif çözüm yolları geliştirilip, yargı organlarının geneline yaygınlaştırılabilir. Böylece usul ekonomisi ve adalete erişim gibi yargılama ilkelerinin işlerliği artırılabilecektir.

\section{Sonuç}

Dijital çağın getirdiği yeniliklere uyum sağlama ve avantajlarından faydalanabilme adına birçok alanda dönüşüme gidilmiştir. Ticari, teknik, hukuki olmak üzere pek çok alanda değişimi meydana getiren bu sürecin izdüşümü uyuşmazlıkların çözümüne de yansımıştır. Bu değişim, hukuki uyuşmazlıkların ve çalışmanın temelini oluşturan vergi uyuşmazlıklarının çözümünde dijital imkânlardan yararlanma fikrini ortaya çıkarmıştır. Bilhassa COVID-19 sürecinde tüm dünyada zorunlu bir değişimin ortaya çıktığı günümüz şartları açısından değerlendirildiğinde uyuşmazlıkların çözümünde çevrim içi yolların rolü daha kolay anlaşılabilir.

Çevrim içi uyuşmazlık yolları, teknoloji aracılığıyla çevrim içi uyuşmazlık yollarına başvuru, belge yükleme, görüntüleme, değerlendirme ve uyuşmazlığın e-ADR yolları ile hızlı bir şekilde çözümlenmesi sürecini içeren tüm vasıtalardır. ODR içinde çeşitli avantaj ve dezavantajları barındırmaktadır. Özellikle çevrim içi çözüm yollarının dar anlamını ifade eden e-ADR uygulamasında; uyuşmazlığın niteliğine ve uygun tekniğin seçilip seçilmediğine bağlı olarak bu avantaj veya dezavantajlar gün yüzüne çıkacaktır.

Vergi yargısının temel işlevlerinden biri uyuşmazlıkları sona erdirmedir. Bu işlevini yerine getirirken yargı öncesi, yargılama aşaması veya yargı sonrası mekanizmalar oluşturulabilir. Günümüz uyuşmazlık çözüm sistemleri içinde önemli olan bu uyuşmazlıkları önleyici tedbirlerinin geliştirilmesi ve uygulanmasıdır. Uyuşmazlığın esasen taraflar arasında giderilmesine yönelik süreçlerin oluşturulması gereklidir. Türkiye'de hukuk yargılamasında alternatif çözüm yolları belli uyuşmazlıkların çözümüne ilişkin olarak uygulanmaktadır. 
Yasal olarak bu yolların elektronik olarak uygulanmasına engel bir durum yoktur. 2010 yılının başlarından itibaren çeşitli ülkelerde kademe kademe vergi uyuşmazlıklarının çözümünde uygulanan arabuluculuk, tahkim gibi alternatif çözüm yollarının dijital olarak uygulanabilirliği tartışmaya açılmış ve çeşitli ülkelerde uygulamaya geçirilmiştir. Ülke örneklerinden görüldüğü üzere farklı ülkelerde e-ADR vergi uyuşmazlıkların çözümünde bir araç olarak kullanılmaktadır. Türkiye'de de mevzuat değişikliği kapsamında her vergi uyuşmazlığında değil, fakat idarenin takdir yetkisine sahip olduğu alanlara ilişkin ortaya çıkan uyuşmazlıklarda bu yollara başvurulabilir. Vergi idaresine takdir yetkisi tanındığı ve uyuşmazlığa en sık konu olan hallere örnek olarak; re'sen tarhiyat işlemlerinin dayanağını oluşturan takdir komisyonu kararları ve vergi inceleme raporlarına dayalı tarhiyatlar, mücbir sebep ve zor durumda süre tanınması, uzlaşmaya başvuru şartlarından olan kanun hükmüne yeterince nüfuz edilememesi konusunda idareye tanınan yetki kapsamında uzlaşma talebinin reddine ilişkin durumlar gösterilebilir. İdarenin takdir yetkisi kullanımı kanuni, açık bir ölçüye değil, sübjektif bir değerlendirmeye dayanır. Vergi idaresinin bireysel idari işlemlerde takdir yetkisini kullanırken yetki sınırını aşması ve açık takdir hataları yapması olasıdır. İşte bu durumdan kaynaklanan uyuşmazlıkların çevrimiçi alternatif çözüm yolları ile dostane bir şekilde çözümlenmesi sağlanabilir. Bu şekilde vergi yargısının iş yükü azaltılabilir, yargı fonksiyonuna işlerlik kazandırılabilir.

ODR, sadece alternatif çözüm yollarının çevrim içi yapılmasını değil, yargılamaya işlerlik kazandıracak tüm uygulamaların ve sürecin çevrim içi gerçekleştirilmesini içerir. Türkiye'de UYAP ile yargılamaya ilişkin birçok prosedürün internet üzerinden yapılıyor olması olumlu bir gelişmedir. Ayrıca e-ADR uygulamaları, yasal zemin oluşturulmasıyla birlikte vergi uyuşmazlıklarının çözüm sistemine dahil edilebilir. Bu uyuşmazlıkların doğasına uygun alternatiflerin uyarlanması ve maliyetlerin düşük tutulması sağlanmalıdır. Bu şekilde usul ekonomisi ilkesi, adalete erişim ve diğer yargılama ilkelerinin işlerliği artırılacaktır. Sonuç olarak Türkiye'de vergi uyuşmazlıklarının yargısal çözümünde çevrim içi ortamda başvuru imkânı sunulmasının önemli bir gelişme olduğu, bununla birlikte çağın gereği olarak e-ADR ile uyuşmazlıkların çözümünü sağlayan hibrit bir uyuşmazlık çözüm sistemi geliştirilmesi gerekliliğine ulaşıımıştır.

\section{Beyan ve Açıklamalar (Declarations and Disclosures)}

Yazarların Etik Sorumlulukları (Ethical Responsibilities of Authors): Bu çalışmanın yazarı, araştırma ve yayın etiği ilkelerine uyduğunu kabul etmektedir.

Çıkar Çatışması (Conflicts of Interest): Yazar tarafından herhangi bir çıkar çatışması beyan edilmemiştir.

Finansal Destek (Funding): Yazar, çalışmanın hazırlanması ve/veya yayınlanması sürecinde herhangi bir finansal destek almamıştır.

Yazar Katkı Oranı (Author Contributions): Yazar; kavramlaştırma ve çalışma dizaynı, literatür taraması ve analizi, çalışmanın ilk/taslak halinin yazılması, çalışmanın gözden geçirilmesi ve düzenlenmesi/düzeltilmesi aşamalarından tek başına sorumlu olduğunu beyan etmektedir.

Intihal Denetimi (Plagiarism Checking): Bu çalışma, intihal tarama programı kullanılarak intihal taramasından geçirilmiştir.

\section{Son Notlar}

1. Türk hukuk sisteminde zorunlu alternatif çözüm yolları; Mecburi Tahkim Kanunu'na tabi uyuşmazlıklar (3533 sayılı Kanun), Tüketicinin Korunması Hakkında Kanun hükümlerine göre tüketici hakem heyetlerine başvurunun zorunlu olduğu hâller (TKHK, 73/a), spor federasyonlarııın spor faaliyetlerinin yönetimine ve disiplinine ilişkin kararlarına karşı tahkime başvurunun zorunlu olduğu hâller (1982 Anayasası, 59/3) ve iş uyuşmazlıklarında (4857 sayılı iş Kanunu, madde 20 ve 7036 sayılı is Mahkemeleri Kanunu); ticari uyuşmazlıklarda (6102 sayılı TTK, 5/a) ve abonelik sözleşmelerinden doğan uyuşmazlıklarda (7155 sayılı Kanun, madde 20) arabuluculuğunun zorunlu olduğu alanlardan oluşmaktadır. 


\section{Kaynaklar}

Adalet Bakanlığı (2021a). UYAP bilişim sistemi. Bilgi İşlem Genel Müdürlüğü, Ankara, https://www.uyap.gov.tr/Kitap (Erişim Tarihi: 15 Ocak 2021).

Adalet Bakanlığı (2021b). E-duruşma bilgilendirme. https://edurusmabilgi.adalet.gov.tr/ (Erişim Tarihi: 12 Mart 2021$)$.

Adalet Bakanlığı (2020a). Adalet hizmetlerinde koronavirüs tedbirleri kapsamında yeni çalışma esasları kılavuzu. https://rayp.adalet.gov.tr/Resimler/1/dosya/brosur.pdf (Erişim Tarihi: 15 Ocak 2021).

Adalet Bakanlığı (2020b). E-duruşma avukat kullanım kılavuzu. Bilgi İşlem Genel Müdürlüğü, e-durusma-avukatkullanim-klavuzu05-11-202014-11.pdf (adalet.gov.tr) (Erişim Tarihi: 15 Ocak 2021).

Adalet Bakanlığı (2019). Yargı reformu stratejisi. Strateji Geliştirme Daire Başkanlığı, https://sgb.adalet.gov.tr/Resimler/SayfaDokuman/23122019162931YRS_TR.pdf (Erişim Tarihi: 15 Ocak 2021).

Adalet Bakanlığı (2015). Yargı reformu stratejisi. Strateji Geliştirme Daire Başkanlığı, https://sgb.adalet.gov.tr/Resimler/SayfaDokuman/23122019163004yargi_reformu_stratejisi.pdf (Erişim Tarihi: 15 Ocak 2021).

Adli Sicil ve İstatistik Genel Müdürlüğü (2020). Adli istatistikler 2019. Ankara, 1062020170359HizmeteOzel-2019-baskıiSA.pdf (adalet.gov.tr) (Erişim Tarihi: 10 Ocak 2021).

Arat, N. (2011). İdari uyuşmazlıkların alternatif uyuşmazlık çözüm yöntemleri ile halli önündeki engeller. İstanbul Üniversitesi Hukuk Fakültesi Mecmuası, 69(1-2), 891-906.

Austin, C. (2018). Online and automated dispute resolution in New Zealand: A law reform and regulation perspective. Victoria University of Wellington Legal Research Papers Student and Alumni Paper Series (Ed. John Prebble, Mamari Stephens), 20/2018.

Benyekhlef, K., \& Gélinas, F. (2005). Online Dispute Resolution. Lex Electronica, 10(2), https://www.lexelectronica.org/files/sites/103/10-2_benyekhlef-gelinas.pdf (Erişim Tarihi: 10 Ocak 2021).

Carabetta, G. (2017). Alternative dispute resolution in public, essential and emergency services. Australian Business Law Review, 45, 243-259.

Clark, E., Cho, G., \& Hoyle, A. (2003). Online dispute resolution: Present realities, pressing problems and future prospects. International Review of Law Computers \& Technology, 17(1), 7-25.

Cortés, P. (2014). Online dispute resolution services: A selected number of case studies. Computer and Telecommunications Law Review, 20(6), 172-178.

Cortés, P. (2010). Online dispute resolution for consumers in the European Union. Routledge Research in IT and Ecommerce Law. London: Routledge, Taylor \& Francis Group.

Dimov, D. V. (2017). Crowdsourced online dispute resolution. eLAW - Leiden University Center for Law and Digital Technologies, SIKS Dissertation series no. 2017-17.

Ebner, N., \& Greenberg, E. E. (2020). Strengthening online dispute resolution justice. Washington University Journal of Law \& Policy, 63, 65-118.

Gregory, J. D. (2011). Current practices of online dispute resolution - the Canadian experience. E-Commerce and ODR: Current Status and Prospects in the Region Seoul, Korea. September 20-21.

Hidayah, K. (2018). Indonesian tax dispute resolution in cooperative paradigm compared to United Kingdom and Australia. IOP Conf. Series: Earth and Environmental Science, 175, 1-6.

Hout, D. (2018). Is mediation the panacea to the profusion of tax disputes? World Tax Journal, 10(1), 43-97.

Jone, M. (2019). The Internal Revenue Service's Future State initiative and its impact on the tax dispute resolution system of the United States: A dispute system design perspective. eJournal of Tax Research, 16(3), 824-851.

Jone, M. (2015). Evaluating Australia's tax dispute resolution system: A dispute systems design perspective. eJournal of Tax Research, 13(2), 552-580.

Kadıoğlu, C. Ç. (2019). Bricks and Clicks: Online dispute resolution mechanisms and implementation of online arbitration in Turkey for cross-border business to consumer e-commerce disputes. Bilişim Hukuku Dergisi, 1(1), 113-146.

Kovač, P. (2018). The potentials and limitations of tax dispute prevention and alternative resolution mechanisms. Portal of Croatian Scientific and Professional Journal, 39(4), 1505-1531.

Larson, D. A. (2019). Digital accessibility and disability accommodations in online dispute resolution: ODR for everyone. Ohio State Journal on Dispute Resolution, 34(3). Available at SSRN: https://ssrn.com/abstract=3408885 
Latifah, E., Bajrektarevic, A. H., \& Imanullah, M. N. (2019). The shifting of alternative dispute resolution: From Traditional form to the online dispute resolution. Brawijaya Law Journal, 6(1), 27-37.

Li, J., Bao, N. J., Hu, S., Hu, W., \& Zerbino, M. (2020). Digitalization and international tax dispute resolution: A window of opportunity for BRITACOM. Articles \& Book Chapters. 2803. https://digitalcommons.osgoode.yorku.ca/scholarly_works/2803 (Erişim Tarihi: 10 Ocak 2021).

Mookhey, S. (2013). Tax disputes system design. eJournal of Tax Research, 11(1), 79-97.

Nam, B. T., \& Walpole, M. (2016). Tax disputes, litigation costs and access to tax justice. eJournal of Tax Research, 14(2), 319-336.

Özkan Sungurtekin, M. (2015). Anayasal şikâyet ve adalete erişim. Dokuz Eylül Üniversitesi Hukuk Fakültesi Dergisi, 16(Prof. Dr. Hakan Pekcanıtez Armağan Özel Sayısı), 399-410.

Pappas, B. A. (2008). Online court: Online dispute resolution and the future of small claims. UCLA Journal of Law \& Technology, 12(2), 1-25.

Rabinovich Einy, O., \& Katsh, E. (2017). A new relationship between public and private dispute resolution: Lessons from online dispute resolution. Ohio State Journal on Online Dispute Resolution, 32(4), 695-724.

Rabinovich Einy, O., \& Katsh, E. (2014). Digital justice reshaping boundaries in an online dispute resolution environment. International Journal of Online Dispute Resolution, 1(1), 5-36.

Ramasastry, A. (2004). Government-to-citizen online dispute resolution: A preliminary inquiry. Washington Law Review, 79 Wash. L. Rev. 159, 159-174.

Salter, S. (2017). Online dispute resolution and justice system integration: British Columbia's civil resolution tribunal. Windsor Yearbook of Access to Justice, 34(1), 112-129.

Sela, A. (2017). The effect of online technologies on dispute resolution system design: Antecedents, current trends and future directions. Lewis \& Clark Law Review, 21(3), 633-682.

Schiavetta, S. (2005). Online dispute resolution and e-government: Overcoming the digital divide. 20th BILETA Conference: Over-Commoditised; Over-Centralised; Over Observed: the New Digital Legal World?, April, 1-9.

Schultz, T. (2002). Online dispute resolution: An overview and selected issues. United Nations Economic Commission for Europe Forum on Online Dispute Resolution, Geneva, 6-7 June.

Sharmila, M. S. (2020). Online dispute resolution and computational law a study on digital justice. International Journal of Advanced Research in Engineering and Technology (IJARET), 11 (9), 36-41.

Stilwell, K. D. (2014). Mediation of Canadian tax disputes. University of Toronto Faculty of Law the degree of Master of Laws.

Sourdin, T. (2015). Evaluating alternative dispute resolution (ADR) in disputes about taxation. SSRN Electronic Journal, 34(1), 19-31.

Tekbaş, A., \& Hayrullahoğlu, B. (2018). Vergi uyuşmazılıkları bakımından makul sürede yargılanma hakkı. Maliye Dergisi, $175,253-274$

Ziemblicki, B. (2018). Going online- Is the world ready to replace litigation with online dispute resolution mechanisms? Wroclaw Review of Law, Administration \& Economics, 5(2), 40-51.

Xu, Z., Zhang, C., \& Gao, J. (2008). An architecture and issues for online dispute resolution with fairness and justice. 2008 Chinese Control and Decision Conference, 3966- 3970.

Verma, D., Banwari, A., \& Pande, N. (2018). Online dispute resolution. (Ed.) B. Pena-Acuna, Digital communication management (pp.139-149). London: IntechOpen. 
This Page Intentionally Left Blank 